\title{
FAKTOR-FAKTOR YANG BERHUBUNGAN DENGAN TERJADINYA PERNIKAHAN DINI DI DESA SUNGGAL KANAN KABUPATEN DELISERDANG
}

\author{
Yulina Dwi Hastuty ${ }^{1}$ \\ 1Jurusan Kebidanan Poltekkes Kemenkes Medan \\ Corresponding author : yulinadwihastuty@gmail.com
}

\begin{abstract}
Abstrak
Dampak negatif yang ditimbulkan pernikahan dini pada remaja adalah kurang siapnya psikologi, putusnya akses pendidikan dan komplikasi kehamilan dan persalinan. Kehamilan remaja akan meningkatkan resiko dua hingga empat kali lebih tinggi dibandingkan usia perempuan yang hamil pada usia lebih dari 20 tahun. Data dari United Nations International Children's Emergency Fund (UNICEF) di Asia Selatan mendapati $48 \%$ dari 9,7 juta anak perempuan telah menikah sebelum usia 18 tahun sedangkan untuk tahun 2000 angka pernikahan dini hampir ditemukan di seluruh provinsi di Indonesia bahkan sekitar 10\% remaja puteri melahirkan anak pertamanya pada usia 15-19 tahun. Tujuan penelitian ini adalah untuk mengetahui bagaimana hubungan pendidikan, tingkat ekonomi keluarga, dukungan keluarga dan sumber informasi dengan terjadinya pernikahan dini. Penelitian bersifat studi korelasi dengan pendekatan Cross Sectional dan jenis data primer. Populasi sebanyak 136 responden dan sampel sebanyak 37 responden dengan menggunakan metode accidental Sampling. Data dianalisis secara univariat dan bivariat menggunakan uji korelasi Sphearman. Hasil penelitian menunjukkan bahwa pernikahan dini memiliki hubungan cukup kuat dengan pendidikan dimana rho sebesar $-0,369$. Ditemukan hubungan cukup kuat dengan tingkat ekonomi keluarga dimana rho sebesar $-0,476$. Hubungan kuat dengan dukungan keluarga dimana rho sebesar $-0,596$ dan hubungan yang kuat juga ditemukan dengan sumber informasi dimana rho sebesar 0,691, sehingga dapat disimpulkan bahwa ada hubungan antara faktor pendidikan, tingkat ekonomi keluarga, dukungan keluarga, sumber informasi dengan terjadinya pernikahan dini.
\end{abstract}

Kata Kunci : Pernikahan dini; remaja; kehamilan; persalinan 


\title{
Factors Related to Early Marriage in Sunggal Kanan Deliserdang
}

\begin{abstract}
The negative impact of early marriage in adolescents are less readily as psychology, breaking access to education and complications of pregnancy and childbirth. Teenage pregnancy increases the risk two to four times higher than the age of women who are pregnant at the age of over 20 years. Data from the United Nations International Children's Emergency Fund (UNICEF) in South Asia found that $48 \%$ of the 9.7 million girls are married before the age of 18 years, while for 2000, the rate of early marriage are found in almost all provinces in Indonesia and even about $10 \%$ girls gave birth to her first child at the age of $15-19$ years. The purpose of this study was to determine how the relationship of education, family economic level, family support and resources to early marriage. The study is a correlation study with cross sectional approach and the type of primary data. Population of 136 respondents and a sample of 37 respondents using accidental sampling method. Data was analyzed by univariate and bivariate correlation test Sphearman. The results showed that early marriage has a strong enough relationship with education where rho of -0.369 . Found a strong enough relationship with the economic level of families where rho -0.476. Strong relationships with family support where rho amounting to -0.596 and also found a strong relationship with resources where rho of 0.691 , so it can be concluded that there is a correlation between education, family economic level, family support, resources with early marriage
\end{abstract}

Keywords: Early marriage; adolescent; pregnancy; childbirth 


\section{Pendahuluan}

Masa remaja merupakan masa dimana pertumbuhan dan perkembangannya telah mengarah kepada kematangan seksual dengan memantapkan identitas dirinya sebagai individu yang terpisah dari keluarganya dan persiapan dalam menentukan masa depannya. Usia remaja menimbulkan berbagai dampak seperti kurangnya pengetahuan tentang seks, kehidupan rumah tangga serta adat istiadat yang merasa malu menikah di usia tua sehingga menyebabkan meningkatnya pernikahan dini ${ }^{1}$.

Dampak negatif lain yang ditimbulkan dari pernikahan dini pada remaja diantaranya kurang siapnya psikologi, putusnya akses pendidikan dan komplikasi kehamilan misalnya anemia, aborsi, intrauteri fetal death, dan atonia uteri 2. Dahulu, pernikahan dianggap hal yang biasa saat seorang perempuan menikah di bawah usia 15 tahun. Akan tetapi, pro dan kontra pernikahan dini mencuat setelah muncul pemberitaan kontroversial pernikahan Syekh Puji yang berusia 43 tahun dengan Ulfah Lutfiana yang masih berusia 12 tahun $^{3}$. Menurut Luthfil (2010) menyimpulkan terjadi banyak pasangan nikah yang meninggalkan tradisi pernikahan dini dengan alasan karena berbuah pada rumitnya menjalin keluarga harmoni ${ }^{4}$. Calon pasangan nikah lebih suka melestarikan adat perkawinan lain yaitu menikah pada usia di atas batas yang telah mentradisi ${ }^{5}$

Hasil survei yang dilakukan United Nations International Children's Emergency Fund (UNICEF) di Asia Selatan mendapati $48 \%$ dari 9,7 juta anak perempuan telah menikah sebelum usia 18 tahun, Bangladesh 25,9\% dari 3382 remaja putri dan Amerika Serikat hanya 2,5\%. Pada tahun 2000 bahwa angka pernikahan dini hampir ditemukan di seluruh provinsi di Indonesia bahwa sekitar $10 \%$ remaja puteri melahirkan anak pertamanya pada usia 15-19 tahun. Kehamilan remaja akan meningkatkan resiko dua hingga empat kali lebih tinggi dibandingkan usia perempuan yang hamil pada usia lebih dari 20 tahun ${ }^{6}$. Menurut United Nation Fund for Population Activities(UNFPA) atau lembaga Persatuan Bangsa Bangsa yang fokus terhadap isu kependudukan dunia, menyoroti persoalan kehamilan yang dialami oleh remaja perempuan bahwa ada sekitar 16 juta remaja perempuan usia 15-19 tahun yang melahirkan setiap tahunnya ${ }^{7}$.

Survei Demografi dan Kesehatan Indonesia (SDKI) tahun 2007 mencatat jumlah kasus pernikahan dini mencapai 50 juta penduduk dengan rata-rata usia 16-20 tahun ${ }^{8}$. Tahun 2008 dilaporkan sekitar 25\% penduduk Indonesia menikah pada usia dini atau di bawah usia ideal yang dianjurkan pemerintah yaitu 21 tahun untuk perempuan dan 25 tahun untuk laki-laki. Tahun 2009 dilaporkan pasangan yang menikah di bawah umur 20 tahun sebanyak 32.483 orang dari total pasangan usia subur sebanyak 732.206 orang. Tahun 2010 dilaporkan pernikahan di usia 15-19 tahun mencapai 41,9 persen. Ada pula pernikahan pada usia sangat muda, usia 10-14 tahun sebesar 4,8\% 9. Di beberapa daerah didapatkan bahwa sepertiga dari jumlah pernikahan terdata dilakukan oleh pasangan usia di bawah 16 tahun. Jumlah kasus pernikahan dini di Indonesia mencapai 50 juta penduduk dengan rata-rata usia perkawinan 19,1 tahun. Di Jawa Timur $39,4 \%$, Jawa Barat 36\%, Kalimantan Selatan 35,5\% dan Jambi 30,6\% .

Berdasarkan penelitian yang dilakukan oleh Pusat Penelitian Kependudukan UNPAD bekerja sama dengan BKKBN Jawa Barat melaporkan umur kawin muda di daerah pantai masih tinggi yaitu $36,7 \%$ pada umur 12-14 tahun, 56,7\% umur 15-19 tahun dan 6,6\% umur 20-24 tahun, dengan faktor yang melatarbelakangi adalah rendahnya tingkat pendidikan dan budaya ${ }^{10}$. 
Berdasarkan survei awal, yang dilakukan dari jumlah penduduk 1746 KK di Desa Sunggal Kanan terdapat sebanyak 136 KK yang menikah di usia < 20 tahun, dengan persentasi laki-laki 4,18\% (73 KK) dan perempuan $3,60 \%$ (63 KK). Sebagai akibat dari pernikahan dini tersebut, didapati bahwa $85 \%$ dari 92 orang jumlah ibu hamil saat melakukan pemeriksaan ANC di Balai Desa Sunggal Kanan adalah anemia (kekurangan zat besi) dan seorang ibu dengan riwayat abortus tiga kali (abortus habitualis). Sampai saat ini belum ada dilakukan penelitian tentang hal-hal yang melatarbelakangi terjadinya pernikahan dini. Tujuan dari penelitian ini untuk mengetahui Faktor-Faktor Yang Berhubungan Dengan Terjadinya Pernikahan Dini di Desa Sunggal Kanan kabupaten Deli Serdang.

\section{Metode}

Penelitian ini menggunakan desain studi kolerasi, dengan metode pendekatan Cross Sectional. Jumlah populasi sebanyak 136 orang yang menikah dibawah usia 20 tahun. Kriteria sampel yang diteliti adalah responden yang menikah dini dan batas usia saat ini hanya sampai 35 tahun (batas usia reproduksi). Sampel yang digunakan dalam penelitian ini sebanyak 37 orang yang diambil berdasarkan tekhnik accidental sampling. Jenis data yang digunakan dalam penelitian ini adalah data primer yang diperoleh langsung dari responden dengan menggunakan daftar check list. Analisa data dilakukan dengan uji korelasi Sphearman menggunakan SPSS.

\section{Hasil Penelitian}

1. Analisa Univariat

Analisa Univariat dilakukan untuk melihat distribusi frekuensi faktor - faktor yang berhubungan dengan terjadinya pernikahan dini, meliputi Pendidikan, Tingkat Ekonomi Keluarga, Dukungan Keluarga dan Sumber Informasi.

Tabel 1. Distribusi Frekuensi Berdasarkan Pendidikan, Tingkat Ekonomi Keluarga, Dukungan Keluarga dan Sumber Informasi Responden di Desa Sunggal Kanan.

\begin{tabular}{lcc}
\hline \multicolumn{1}{c}{ Variabel } & Frekuensi & Persentasi (\%) \\
\hline Pendidikan Terakhir & & \\
Pendidikan Dasar & 22 & 59,5 \\
Pendidikan Menengah & 15 & 40,5 \\
\hline Total & 37 & 100 \\
\hline Tingkat Ekonomi Keluarga & & \\
< Upah Minimum & 19 & 51,4 \\
>Upah Minimum & 18 & 48,6 \\
\hline Total & 37 & 100 \\
\hline Dukungan Keluarga & & \\
Tidak Ada & 12 & 32,4 \\
Ada & 25 & 67,6 \\
\hline Total & 37 & 100 \\
\hline Sumber Informasi & & \\
Lingkungan & 16 & 43,2 \\
Media Massa & 13 & 35,1 \\
Tenaga Kesehatan & 8 & 21,6 \\
\hline Total & 37 & 100 \\
\hline
\end{tabular}


Tabel 1 di atas menunjukkan bahwa mayoritas responden yang menikah dini dengan latar belakang pendidikan dasar (SD-SMP) sebanyak 22 responden (59,5\%), tingkat ekonomi keluarga di bawah upah minimum sebanyak 19 responden (51,4\%), mendapat dukungan dari keluarga sebanyak 25 responden $(67,6 \%)$ dan mendapat informasi tentang pernikahan dini dari lingkungan sebanyak 16 responden $(43,2 \%)$
2. Analisa Bivariat

Analisa Bivariat dilakukan untuk mengetahui ada tidaknya hubungan yang bermakna antara faktor - faktor yang berhubungan dengan terjadinya pernikahan dini seperti pendidikan terakhir, tingkat ekonomi keluarga, dukungan keluarga dan sumber informasi di Desa Sunggal Kanan . Keterkaitan antara faktor-faktor yang berhubungan dengan terjadinya pernikahan dini dan seberapa besar hubungan antara faktor-faktor tersebut secara rinci dapat dilihat pada tabel 2 dibawah ini.

Tabel. 2 . Rekapitulasi Hasil Uji Korelasi Sphearman Faktor -faktor yang berhubungan Dengan Terjadinya Pernikahan Dini

\begin{tabular}{|c|c|c|c|c|}
\hline \multicolumn{5}{|c|}{ Terjadinya Pernikahan Dini } \\
\hline \multirow{2}{*}{ Variabel } & \multicolumn{2}{|c|}{ Menikah Dini } & \multicolumn{2}{|c|}{ Uji Sphearman } \\
\hline & $\mathbf{F}$ & $\%$ & Rho & Sig \\
\hline \multicolumn{5}{|l|}{ Pendidikan } \\
\hline Pendidikan Dasar & 22 & 59,5 & \multirow{3}{*}{$-0,369$} & \multirow{3}{*}{0,012} \\
\hline Pendidikan Menengah & 15 & 40,5 & & \\
\hline Total & 37 & 100 & & \\
\hline \multicolumn{5}{|l|}{ Tingkat Ekonomi Keluarga } \\
\hline$<$ Upah Minimum & 19 & 51,4 & & \\
\hline > Upah Minimum & 18 & 48,6 & $-0,476$ & 0,003 \\
\hline Total & 37 & 100 & & \\
\hline \multicolumn{5}{|l|}{ Dukungan Keluarga } \\
\hline Tidak Ada & 12 & 32,4 & & \\
\hline $\mathrm{Ya}$ & 25 & 67,6 & $-0,596$ & 0,000 \\
\hline Total & 37 & 100 & & \\
\hline \multicolumn{5}{|l|}{ Sumber Informasi } \\
\hline Lingkungan & 16 & 43,2 & & \\
\hline Media & 13 & 35,1 & & \\
\hline Tenaga Kesehatan & 8 & 21,6 & 0,691 & 0,000 \\
\hline Total & 8 & 100 & & \\
\hline
\end{tabular}

Berdasarkan tabel 2 didapati bahwa analisis uji korelasi Sphearman untuk pendidikan terakhir dengan terjadinya pernikahan dini memperoleh angka koefisien korelasi - 0,369 yang berarti ada korelasi cukup kuat antara pendidikan dengan terjadinya pernikahan dini di Desa Sunggal Kanan dan angka signifikansi yang diperoleh sebesar 0,012<0,05 yang berarti adanya hubungan yang signifikan antara pendidikan dengan terjadinya pernikahan dini di Desa Sunggal Kanan. Untuk tingkat ekonomi keluarga dengan terjadinya pernikahan dini diperoleh angka koefisien korelasi $-0,476$ yang berarti ada korelasi cukup kuat antara tingkat ekonomi keluarga dengan terjadinya pernikahan dini dan angka signifikansi yang diperoleh sebesar 
$0,003<0,05$ yang berarti adanya hubungan yang signifikan antara tingkat ekonomi keluarga dengan terjadinya pernikahan dini, untuk dukungan keluarga dengan terjadinya pernikahan dini diperoleh angka koefisien korelasi - 0,596 yang berarti ada korelasi kuat antara dukungan keluarga dengan terjadinya pernikahan dini dan angka signifikansi yang diperoleh sebesar $0,000<0,05$ yang berarti adanya hubungan yang signifikan antara dukungan keluarga dengan terjadinya pernikahan dini dan untuk sumber informasi dengan terjadinya pernikahan dini diperoleh angka koefisien korelasi 0,691 yang berarti ada korelasi kuat antara sumber informasi dengan terjadinya pernikahan dini dan angka signifikansi yang diperoleh sebesar 0,000 $<0,05$ yang berarti adanya hubungan yang signifikan antara sumber informasi dengan terjadinya pernikahan dini di Desa Sunggal Kanan.

\section{Pembahasan}

1. Hubungan Pendidikan dengan Terjadinya Pernikahan Dini

Berdasarkan hasil penelitian, diketahui bahwa mayoritas responden yang menikah dini dengan latar belakang pendidikan dasar (SD - SMP) sebanyak 22 responden $(59,5 \%)$ dan minoritas responden dengan latar belakang pendidikan menengah (SMA) sebanyak 15 responden (40,5\%).

Hasil analisis uji korelasi Sphearman menunjukkan ada korelasi cukup kuat antara pendidikan dengan terjadinya pernikahan dini di Desa Sunggal Kanan. Hal ini sesuai dengan penelitian Fatmawati di Kecamatan Sragi Kabupaten Pekalongan tahun 2009, dengan jumlah responden sebanyak 84 responden didapati bahwa yang melakukan pernikahan dini sebanyak $54,8 \%$, berpendidikan dasar sebanyak $82,1 \%$ dan berdasarkan uji Fisher Exact diperoleh ada hubungan pendidikan dengan nilai $\mathrm{p}$ value $=0,0001$ serta berpengetahuan kurang sebanyak $86,7 \%$ dan berdasarkan uji Pearson
Chi Square diperoleh ada hubungan pengetahuan dengan nilai $p$-value $=0,0001$. Dari hasil tersebut dapat disimpulkan bahwa remaja yang melakukan pernikahan dini dikarenakan pendidikan dasar remaja yang masih rendah dan informasi yang diketahui sedikit serta pengetahuan yang dimiliki kurang tentang usia menikah yang baik ${ }^{11}$.

Sejalan dengan hasil penelitian Rafidah di Kabupaten Purworejo, Jawa Tengah tahun 2009, dengan jumlah responden sebanyak 90 responden didapati bahwa responden dengan latar belakang pendidikan dasar sebanyak 66 responden $(73,3 \%)$ dan responden dengan latar belakang pendidikan menengah sebanyak 24 responden $(26,7 \%)$, dengan nilai $\mathrm{RP}=2,90$, CI $95 \%=1,30-6,49, X^{2}=11,14, \mathrm{p}=0,000$ serta dapat disimpulkan bahwa pendidikan responden yang rendah beresiko 2,9 kali lebih besar menikah pada usia $<20$ tahun dibanding responden dengan pendidikan menengah atau tinggi ${ }^{10}$. Pada penelitian ini, hasil yang didapat adalah semakin rendah pendidikan seseorang maka semakin besar peluang untuk menikah dini dan begitu pun sebaliknya, jika semakin tinggi pendidikan seseorang maka akan semakin kecil peluang untuk menikah dini.

Penelitian ini juga sesuai dengan pendapat Yunus (2010), yang menyatakan bahwa alasan menikah dini adalah mereka yang tidak berpendidikan atau belum sekolah. Hal ini berdampak terhadap ketidakmampuan dalam mengambil keputusan dan di sisi lain tidak mempunyai informasi terkait mengenai kesehatan reproduksi yang benar. Yunus berpendapat bahwa apabila seseorang sudah mendapatkan pendidikan menengah dikatakan cukup paham mengenai baik dan tidaknya menikah usia muda ${ }^{12}$.

Berdasarkan penelitian ini dapat terlihat bbahwa semakin tinggi pendidikan seseorang, maka semakin baik pemahaman, pengetahuan dan keterampilan yang 
dimiliki seseorang dan yang ditemukan peneliti di lapangan adalah seluruh responden yang menjadi sampel dengan latar belakang pendidikan dasar (SD-SMP) dan berpendidikan menengah (SMA) tetap melakukan pernikahan dini. Didapati bahwa lebih banyak dengan latar belakang pendidikan dasar yang menikah di usia lebih dini dibanding dengan berpendidikan menengah.

2. Hubungan Tingkat Ekonomi Keluarga dengan Terjadinya Pernikahan Dini

Diketahui bahwa mayoritas responden yang melakukan pernikahan dini memiliki tingkat ekonomi keluarga di bawah upah minimum sebanyak 19 responden (51,4\%) dan minoritas dengan tingkat ekonomi keluarga di atas upah minimum sebanyak 18 responden $(48,6 \%)$.

Hasil analisis uji korelasi Sphearman menunjukkan ada korelasi cukup kuat antara tingkat ekonomi keluarga dengan terjadinya pernikahan dini di Desa Sunggal Kanan. Hasil ini sejalan dengan penelitian Rafidah di Kabupaten Purworejo tahun 2009, dengan jumlah responden sebanyak 90 responden didapati bahwa responden dengan status ekonomi tinggi sebanyak 35 responden $(38,9 \%)$ dan responden dengan status ekonomi rendah sebanyak 55 responden $(61,1 \%)$, dengan nilai $\mathrm{RP}=1,75, \mathrm{CI}$ $95 \%=1,05-2,91, X^{2}=5,66, p=0,01$ serta dapat disimpulkan bahwa sebagian besar responden yang memiliki tingkat ekonomi yang rendah beresiko 1,75 kali lebih besar menikah pada usia $<20$ tahun dibanding responden yang memiliki ekonomi tinggi dengan Pada hasil penelitian ini menunjukkan bahwa semakin rendah tingkat ekonomi keluarga maka akan semakin tinggi peluang untuk seseorang melakukan pernikahan dini dan begitu juga sebaliknya, semakin tinggi tingkat ekonomi yang dimiliki keluarga makan akan semakin rendah peluang seseorang untuk melakukan pernikahan dini.

Pernyataan senada juga diungkapkan oleh Nirwana (2011) yang menyatakan bahwa sandang, pangan dan papan adalah faktor ekonomi yang merupakan kebutuhan pokok yang menyebabkan suatu perkawinan tidak bisa bertahan hanya dengan ikatan cinta saja, kebutuhan materi harus menjadi pendukungnya ${ }^{13}$.

Hal yang sama dikemukakan oleh Suryaningrum dalam Suhadi (2012) yang menganalisa fenomena pernikahan dini, dimana didapatkan hasil yang menyimpulkan bahwa ada hubungan signifikan antara status ekonomi keluarga, pendidikan orang tua dan pekerjaan terhadap anak-anaknya yang dinikahkan lebih dini.

Berdasarkan hasil penelitian ini menunjukkan bahwa tingkat ekonomi sangat berpengaruh sebagai faktor utama dalam pernikahan dini dikarenakan orangtua beranggapan bahwa anak perempuan merupakan beban ekonomi dalam keluarga dan perkawinan merupakan usaha untuk mempertahankan kehidupan keluarga. Dan ada pula motivasi salah dalam menikah lebih dini yang menyatakan bahwa ketika seseorang menikah dini maka ia akan lebih cepat mendapatkan kemewahan dari pasangannya sendiri dan lepas dari belenggu orang tua dengan tujuan mendapatkan kebebasan.

\section{Hubungan Dukungan Keluarga dengan} Terjadinya Pernikahan Dini

Berdasarkan hasil penelitian diketahui bahwa mayoritas responden yang melakukan pernikahan dini mendapat dukungan keluarga sebanyak 25 responden $(67,6 \%)$ dan minoritas dengan tidak adanya dukungan keluarga sebanyak 12 responden $(32,4 \%)$.

Hasil analisis uji korelasi Sphearman menunjukkan ada korelasi kuat antara 
dukungan keluarga dengan terjadinya pernikahan dini di Desa Sunggal Kanan dan sejalan dengan penelitian Rafidah di Kabupaten Purworejo tahun 2009, dengan jumlah responden sebanyak 90 responden didapati bahwa responden dengan presepsi baik oleh orangtua sebanyak 41 responden $(45,6 \%)$ dan dengan persepsi kurang sebanyak 49 responden $(54,4 \%)$, dengan nilai $\mathrm{RP}=1,5, \mathrm{CI} 95 \%=0,96-2,37, \mathrm{X}^{2}=3,63$, $\mathrm{p}=0,05$ serta dapat disimpulkan bahwa orang tua dengan persepsi kurang akan beresiko 1,5 kali lebih besar menikahkan anaknya pada usia $<20$ tahun dibandingkan orang tua yang memiliki persepsi baik, namun secara statistik tidak bermakna. Hasil penelitian ini juga menyatakan bahwa semakin tinggi dukungan keluarga dalam hal menyetujui menikah lebih dini maka akan besar peluang anak melakukan pernikahan dini dan berlaku juga untuk sebaliknya.

Sependapat juga dengan hasil penelitian Helliyah dalam skripsi Hermawan (2010), menyimpulkan bahwa pernikahan di bawah umur disebabkan adanya tradisi perjodohan yang dilakukan oleh orang tua ${ }^{14}$.

Hal ini juga didukung oleh keputusan yang dinyatakan dalam Deklarasi Hak Asasi Manusia dalam skripsi Fadlyana (2009) juga mendukung hasil penelitian penulis bahwa pernikahan harus dilakukan atas persetujuan penuh kedua pasangan 15 . Namun kenyataannya, yang dihadapi dalam pernikahan usia dini ini, persetujuan menikah sering kali merupakan akumulasi dari paksaan atau tekanan orang tua / wali anak sehingga anak setuju untuk menikah dan merupakan rasa bakti dan hormat pada orang tua. Pernyataan senada juga dikeluarkan oleh International Humanist and Ethical Union, bahwa pernikahan anak merupakan bentuk perlakuan yang salah pada anak (child abuse).

Hasil penelitian yang diperoleh menunjukkan bahwa dukungan keluarga sangat berpengaruh untuk seseorang dapat menikah dini. Hal ini dikarenakan banyak orang tua beranggapan menikahkan anak mereka berarti suatu bentuk perlindungan terhadap sang anak, dengan alasan mencegah anaknya melakukan hal yang diluar jangkauan misalnya telah melakukan hubungan biologis, hamil di luar nikah, kawin lari yang dapat merusak nama baik dalam keluarga. Namun hal ini justru menyebabkan hilangnya kesempatan anak untuk berkembang, tumbuh dan sehat serta kehilangan kebebasan dalam menikah dan untuk keluarga supaya dapat lebih berperan dalam memberikan pendapat maupun motivasi kepada anak agar anak lebih mampu untuk memutuskan dan menunda usia menikah sampai batas usia reproduksi yaitu 20 tahun untuk wanita dan 25 tahun untuk pria.

4. Hubungan Sumber Informasi dengan Terjadinya Pernikahan Dini

Berdasarkan hasil penelitian diketahui bahwa mayoritas responden yang menikah dini mendapat informasi tentang pernikahan dini dari lingkungan sebanyak 16 responden $(43,2 \%)$ dan minoritas didapat dari tenaga kesehatan sebanyak 8 responden (21,6\%).

Hasil analisis uji korelasi Sphearman menunjukkan ada korelasi kuat antara sumber informasi dengan terjadinya pernikahan dini di Desa Sunggal Kanan. Hasil ini juga didukung oleh Tutik (2010), bahwa informasi yang diperoleh dari berbagai sumber dapat memberikan pengaruh jangka pendek sehingga menghasilkan perubahan pengetahuan. Sebagai sarana komunikasi, berbagai bentuk media elektronik seperti televisi, radio dan media massa seperti surat kabar, majalah mempunyai pengaruh besar terhadap penyampaian informasi ${ }^{16}$.

Hasil ini sesuai dengan penelitian Fatmawati di Kecamatan Sragi Kabupaten 
Pekalongan tahun 2009, dengan jumlah responden sebanyak 84 responden didapati bahwa yang melakukan pernikahan dini mendapat informasi yang kurang sebanyak 84,3 dan berdasarkan uji Fisher Exact diperoleh ada hubungan sumber informasi $p$-value $=0,0001$. Hasil penelitian ini juga menyatakan bahwa semakin banyaknya informasi yang tidak tepat didapatkan seseorang baik dari lingkungan ataupun media massa dan elektronik akan memicu seseorang untuk menikah dini karena didasarkan oleh keingintahuan yang akan berdampak buruk baik secara fisik maupun psikologi.

Penelitian ini menunjukkan bahwa Informasi yang diperoleh dari lingkungan lebih berpengaruh dibanding dari media massa. Ini terbukti dari 37 responden terdapat 16 responden mayoritas memperoleh informasi dari lingkungan yaitu keluarga, saudara dan teman sebaya/sepermainan dimana terkadang informasi yang didapat kadang tidak akurat dan bahkan menyimpang sedangkan 13 responden memperoleh informasi dari media massa dimana pengaksesan responden untuk mencari informasi terhalang oleh jarak tempuh dan masih langkanya untuk berakases internet dan jika digunakan pun banyak yang menyalahgunakan dan tidak mencari tentang dampak dari pernikahan dini tersebut. Dalam hal ini keluarga juga berpengaruh untuk turut serta berpartisipasi dalam memberikan pendidikan kesehatan dini kepada anak dan memotivasi anak taat beribadah untuk memperkuat iman / ketaqwaan kepada Yang Maha Kuasa karena didapati banyak anak yang tahu tentang bahaya pernikahan dini akan tetapi karena pergaulan yang terlalu bebas dan tidak adanya pengajaran dari keluarga akan mengakibatkan hal-hal yang tidak diinginkan seperti kawin diluar nikah, aborsi, kawin lari, pemerkosaan yang dapat merusak masa depan seorang anak.

\section{Kesimpulan dan Saran}

\section{Kesimpulan}

Berdasarkan penelitian ini didapatkan kesimpulan bahwa faktor-faktor yang menyebabkan terjadinya pernikahan dini di Desa Sunggal Kanan adalah :

1. faktor pendidikan yang berkorelasi cukup kuat dengan terjadinya pernikahan dini.

2. faktor tingkat ekonomi keluarga yang berkorelasi cukup kuat dengan terjadinya pernikahan dini.

3. faktor dukungan keluarga yang berkorelasi cukup kuat dengan terjadinya pernikahan dini.

4. Juga faktor sumber informasi yang berkorelasi cukup kuat dengan terjadinya pernikahan dini.

\section{Saran}

Adapun saran yang dapat penulis sampaikan bagi Peneliti Selanjutnya untuk melakukan penelitian lanjutan dengan analisis yang lebih luas dengan variabel yang berbeda seperti analisis faktor terhadap pernikahan dini atau analisis dampak dari pernikahan dini tersebut.

\section{Daftar Pustaka}

1. Pieter, H Z dan N L, Lubis, 2010. Psikologi Untuk Kebidanan. Jakarta: Kencana

2. Manuaba, 2008. Memahami Kesehatan Reproduksi Wanita. Jakarta: ECG

3. Janiwarty, Herri, 2013. Pendidikan Psikologi Untuk Bidan Suatu Teori dan Terapannya.

Yogyakarta : Rapha Publishing

4. Luthfil, 2010. Faktor-Faktor Yang Mempengaruhi Pernikahan Usia Dini Perspektif Hukum Islam (Studi Kasus Di Desa Bumirejo Wonosobo Tahun 2009), Yogyakarta. http://digilib.uinsuka.ac.id/pdf. Diakses 16/02/2014 
5. Suhadi, 2012. Pernikahan Dini, Perceraian, dan Pernikahan Ulang : Sebuah Telaah Dalam Perspektif Sosiologi, Jawa Tengah. Jurnal Komunitas. http://journal.unnes.ac.id. Diakses 29/02/2014

6. Widyastuti.dkk.,2009.Kesehatan Reproduksi.Yogyakarta : Fitramaya

7. Fasli, 2013. 16 Juta Remaja Perempuan Menikah Dini. Jakarta. Jakarta Jurnal. http://www.journal.jakarta.go.id/. Diakses 22/04/2014

8. Badan Pusat Statistik. (2008). Survei Demografi dan Kesehatan Indonesia (SDKI) 2007. BPS - BKKBN - Depkes ORC Macro Calverton (USA). Jakarta

9. Prayoga, 2009. 25 Persen Penduduk Indonesia Nikah Dini. Jurnal Kependudukan. Diakses www.google.com/. Diakses $18 / 02 / 2014$

10. Rafidah, 2009. Faktor-Faktor Yang Berhubungan Dengan Pernikahan Usia Dini Di Kabupaten Purwerejo Jawa Tengah, Jawa Tengah. Berita Kedokteran. http:// berita-kedokteran-masyarakat/. Diakses 29/03/2014

11. Fatmawati, 2009. Hubungan Beberapa Faktor Pada Wanita Dengan Kejadian
Pernikahan Usia Dini (Studi Di Kecamatan Sragi Kabupaten Pekalongan Tahun 2009), Jawa Tengah. http://core.kmi.open.ac.uk/pdf.

Diakses 19/02/2014

12. Yunus, dkk, 2010. Ilmu Sosial Dan Budaya Dasar Untuk Kebidanan. Yogyakarta: Fitramaya

13. Nirwana, 2011. Psikologi Kesehatan Wanita. Yogyakarta : Nuha Medika

14. Hermawan, 2010. Pengaruh Pernikahan Dini Terhadap Perceraian Dini (Studi Kasus Di Pengadilan Agama Klaten Tahun 2008-2010), Yogyakarta. http://digilib.uin-suka.ac.id/pdf. Diakses 16/02/2014

15. Fadlyana, Larasaty, 2009. Pernikahan Dini dan Permasalahannya, Bandung. Sari Pediatri. http://saripediatri.idai.or.id/pdfile/11 -2-11.pdf. Diakses 29/03/2014

16. Tutik, 2010. Persepsi Remaja Putri Suku Osing Tentang Usia Pernikahan Yang Sesuai Dengan Kesehatan Reproduksi Wanita. $\quad$ http://adln.lib.unair.ac.id. Diakses 03/03/2014 